\title{
Informed, tailored, and targeted pharmacy support for nurses administering medicines in care homes
}

This article was published in the following Dove Press journal:

Integrated Pharmacy Research and Practice

14 October 2015

Number of times this article has been viewed

Julia Fiona-Maree Gilmartin

Research Department of Practice and Policy, University College, London School of Pharmacy, London, UK
Correspondence: Julia Fiona-Maree Gilmartin

Research Department of Practice and Policy, University College, London School of Pharmacy, 29-39 Brunswick Square, London WCIN IAX, UK

Tel +442077535850

Email j.gilmartin@ucl.ac.uk

\begin{abstract}
Care home nurses could benefit from more informed, tailored, and targeted pharmacy support when undertaking medicine administration. Pharmacists could use the principles of ethnographic research methods to inform, tailor, and target the medicine administration support they provide. It should be determined if existing pharmacy support has been informed following comprehensive observations of care home medicine administration.
\end{abstract}

Keywords: pharmacy, medicine administration, care home, nurses

\section{Care home medicine administration}

As world populations age, the health and welfare of care home residents and care home practices remain popular topics of discussion and research. ${ }^{1,2}$ Large medicine quantities are often used by older care home residents to maintain quality of life. , $^{3,4}$ Therefore, it is important that nurses are supported to administer medicines efficiently, effectively, and safely according to care home medicine management guidelines. ${ }^{5}$

Nurses spend a significant proportion of time administering medicines to care home residents. Residents may require extended periods of time to consume medicines or repeat attempts at administration. This can lead to minimal time gaps between medicine administration rounds and difficulties adhering to administration instructions of time- or food-sensitive medicines. Additionally, this may influence time available to undertake clinical and administrative nurse duties.

In UK care homes, nurses currently receive pharmacy support via medicine record management, medicine-related training, and medicine stock audits, with medicine supply being the main pharmacy service provided in many cases. ${ }^{6,7}$

\section{Pharmacy strategies to support care home medicine administration}

Ethnographic research methods, which include observation, have the potential to explore and understand care home systems and practices and to identify how nurses can be best supported in their medicine management role. ${ }^{2,8}$ Ethnography may be defined as " $[\ldots]$ the study of social interactions, behaviors, and perceptions that occur within groups, teams, organisations, and communities". ${ }^{9}$ It aims to "[...] provide rich, holistic insights into people's views and actions, as well as the nature (that is, sights, sounds) of the location they inhabit, through the collection of detailed observations and interviews". ${ }^{9}$ However, pharmacists in the UK may not routinely and comprehensively use the principles of ethnographic research methods (eg, observation) to inform, tailor, 
and target the medicine administration support they provide to nurses in care homes.

Pharmacists could schedule periods of medicine administration observation at regular intervals throughout the year, following significant changes in medicine administration practices and when changes in nursing staff occur. Medicine administration difficulties could be observed and their association with specific human and environmental factors identified. Strategies to overcome difficulties and facilitate medicine administration could be informed, tailored, and targeted after careful consideration of factors such as interruptions, distractions, and specific medicine administration practices, and resident medicine-taking behaviors. Increased likelihood of successfully supporting the efficiency, effectiveness, and safety of care home medicine administration could therefore occur.

Strategies to address medicine administration difficulties and support nurses could include pharmacists undertaking medicine reviews, ${ }^{10}$ which may lead to suggesting the prescribing of liquid, dissolvable, or non-oral medicine alternatives, and considering opportunities for medicine deprescribing and addressing polypharmacy. ${ }^{11}$ Additionally, topics of nursing staff education could include medicines that should be administered according to strict time or food specifications, medicines that must not be crushed, and strategies to ensure medicines are consumed in their entirety when administered with food or drink.

While these strategies may already have been suggested or implemented in UK care homes, it should be determined if they have been informed, tailored, and targeted toward the needs of individual residents and staff, considering relevant environmental factors observed during care home medicine administration.

\section{Acknowledgment}

Dr Gilmartin is the holder of a Maplethorpe Postdoctoral Fellowship of the University of London.

\section{Disclosure}

The author reports no conflicts of interest in this work.

\section{References}

1. Ibrahim JE, Murphy BJ, Bugeja L, Ranson D. Nature and extent of external-cause deaths of nursing home residents in Victoria, Australia. J Am Geriatr Soc. 2015;63:954-962.

2. Eika M, Dale B, Espnes GA, Hvalvik S. Nursing staff interactions during the older residents' transition into long-term care facility in a nursing home in rural Norway: an ethnographic study. BMC Health Serv Res. 2015;15:1-12.

3. Alldred DP, Barber N, Buckle P, et al. Care Home Use of Medicines Study (CHUMS). The School of Pharmacy, University of London; University of Leeds; University of Surrey; 2009. Available from: http://www. birmingham.ac.uk/Documents/college-mds/haps/projects/cfhep/psrp/ finalreports/PS025CHUMS-FinalReportwithappendices.pdf. Accessed September 7, 2015.

4. Duerden M, Avery T, Payne R. Polypharmacy and Medicines Optimisation. Making it Safe and Sound. London: The King's Fund; 2013.

5. National Institute for Health and Care Excellence [webpage on the Internet]. Managing medicines in care homes. National Institute for Health and Care Excellence; 2014. Available from: https://www.nice. org.uk/guidance/sc1. Accessed September 7, 2015.

6. Royal Pharmaceutical Society Scotland. Improving Pharmaceutical Care in Care Homes. Royal Pharmaceutical Society Scotland; 2012. Available from: https://www.rpharms.com/promoting-pharmacy-pdfs/ rpscarehomereportfinalmarch2012.pdf. Accessed September 7, 2015.

7. Royal Pharmaceutical Society England. Pharmacists Improving Care in Care Homes. Royal Pharmaceutical Society England; 2014. Available from: http://www.rpharms.com/policy-pdfs/pharmacists-improvingcare-in-care-homes.pdf. Accessed September 7, 2015.

8. Savage J. Ethnography and health care. BMJ. 2000;321:1400-1402.

9. Reeves S, Kuper A, Hodges BD. Qualitative research methodologies: ethnography. BMJ. 2008;337:a1020.

10. Alldred D, Barber N, Standage C, Raynor D. How pharmacy can improve medicines use in care homes. BJ Clin Pharm. 2010;2:12-14.

11. Branford D, Butterfield L. Pharmacists should provide services to vulnerable care home residents. Pharm J. 2014;292:81.
Integrated Pharmacy Research and Practice

\section{Publish your work in this journal}

Integrated Pharmacy Research and Practice is an international, peer-reviewed, open access, online journal, publishing original research, reports, reviews and commentaries on all areas of academic and professional pharmacy practice. This journal aims to represent the academic output of pharmacists and pharmacy practice with particular focus on integrated care. All papers are carefully peer reviewed

\section{Dovepress}

to ensure the highest standards as well as ensuring that we are informing and stimulating pharmaceutical professionals. The manuscript management system is completely online and includes a very quick and fair peer-review system, which is all easy to use. Visit http://www.dovepress.com/testimonials.php to read real quotes from published authors. 